\title{
WATER SHORTAGES, DEVELOPMENT, AND DROUGHT IN ROCKLAND COUNTY, NEW YORK ${ }^{1}$
}

\author{
Bradfield Lyon, Nicholas Christie-Blick, and Yekaterina Gluzberg ${ }^{2}$
}

\begin{abstract}
Knowledge of the historical variability of regional climate is an essential element of successful water resource planning. Lacking such perspective, planners and managers can be deceived as to the severity of a recent climate extreme, such as drought, and place a disproportionate blame on the climate, not the integrity of the supply system should water restrictions become necessary to avoid shortages. Presented here is a vivid example of how development, a lack of adequate planning, and climate variability have converged to produce three water emergencies in Rockland County, New York, since 1995. An examination of climate data over the past century indicates that the severity of the recent droughts was well within the range of past variability. Rather than climate alone, the recent water emergencies have highlighted a significant mismatch between supply and demand that has been developing in Rockland County over the past three decades. Substantial development, largely in the form of single-family homes, has not been matched with a corresponding enhancement of the county's water system. Realistic plans for meeting current water demand will require cooperation among all stakeholders, beginning with an acknowledgement that climate variations are inevitable, not the sole source of blame when water shortages arise.
\end{abstract}

(KEY TERMS: climate variability; suburban development; drought; precipitation; water supply.)

Lyon, Bradfield, Nicholas Christie-Blick, and Yekaterina Gluzberg, 2005. Water Shortages, Development, and Drought in Rockland County, New York. Journal of the American Water Resources Association (JAWRA) 41(6):1457-1469.

\section{INTRODUCTION}

At first glance Rockland County, in the southeastern corner of New York State (Figure 1), does not stand out as an area especially prone to water shortages. With year-round precipitation typically in excess of $1,000 \mathrm{~mm}$, an eastern boundary delineated by the Hudson River, and a population of 287,000 in 2000 (a modest 635 persons per $\mathrm{km}^{2}$ ), the county would appear to have an abundant supply of water. Yet on closer inspection Rockland is facing some very real water challenges. Between 1995 and 2002 the county declared three drought emergencies, with the latest round of water shortages being described by one county official as the worst on record (Raver, 2002). Why so many water shortages in such a short period of time? Have regional climate variations over the past decade been especially severe, or is the water supply system itself showing signs of increased vulnerability to the inevitable emergence of episodic droughts?

In this article the relative severity of droughts occurring in the Rockland County region over the past century is assessed, and the county's demographics, water supply system, and development trends are summarized. Based on these evaluations it is argued that, in addition to variations in climate, the string of recent drought emergencies was due to an everincreasing stress on the county's water supply. It is shown that this situation has arisen because continuing development in the county, primarily in the form of private residences, has begun to outstrip the available water supply, a factor that is now gaining increasing attention - and not just in Rockland County. Demand driven drought is a concept that applies universally (e.g., Vorosmarty et al., 2000), although historically it has been deemed applicable mainly in semi-arid regions, such as the southwestern United

\footnotetext{
1Paper No. 04081 of the Journal of the American Water Resources Association (JAWRA) (Copyright (C) 2005). Discussions are open until June 1, 2006.

2Respectively, Associate Research Scientist, International Research Institute for Climate and Society, the Earth Institute at Columbia University, Monell Building, Room 110, Palisades, New York 10964; Professor, Department of Earth and Environmental Sciences and LamontDoherty Earth Observatory of Columbia University, 215 Seismology, Palisades, New York 10964; and Environmental Biology major and Rabi scholar, Department of Ecology, Evolution and Environmental Biology, Columbia University, 10th Floor Schermerhorn Extension, 1200 Amsterdam Avenue, New York, New York 10027 (E-Mail/Lyon: blyon@iri.columbia.edu).
} 


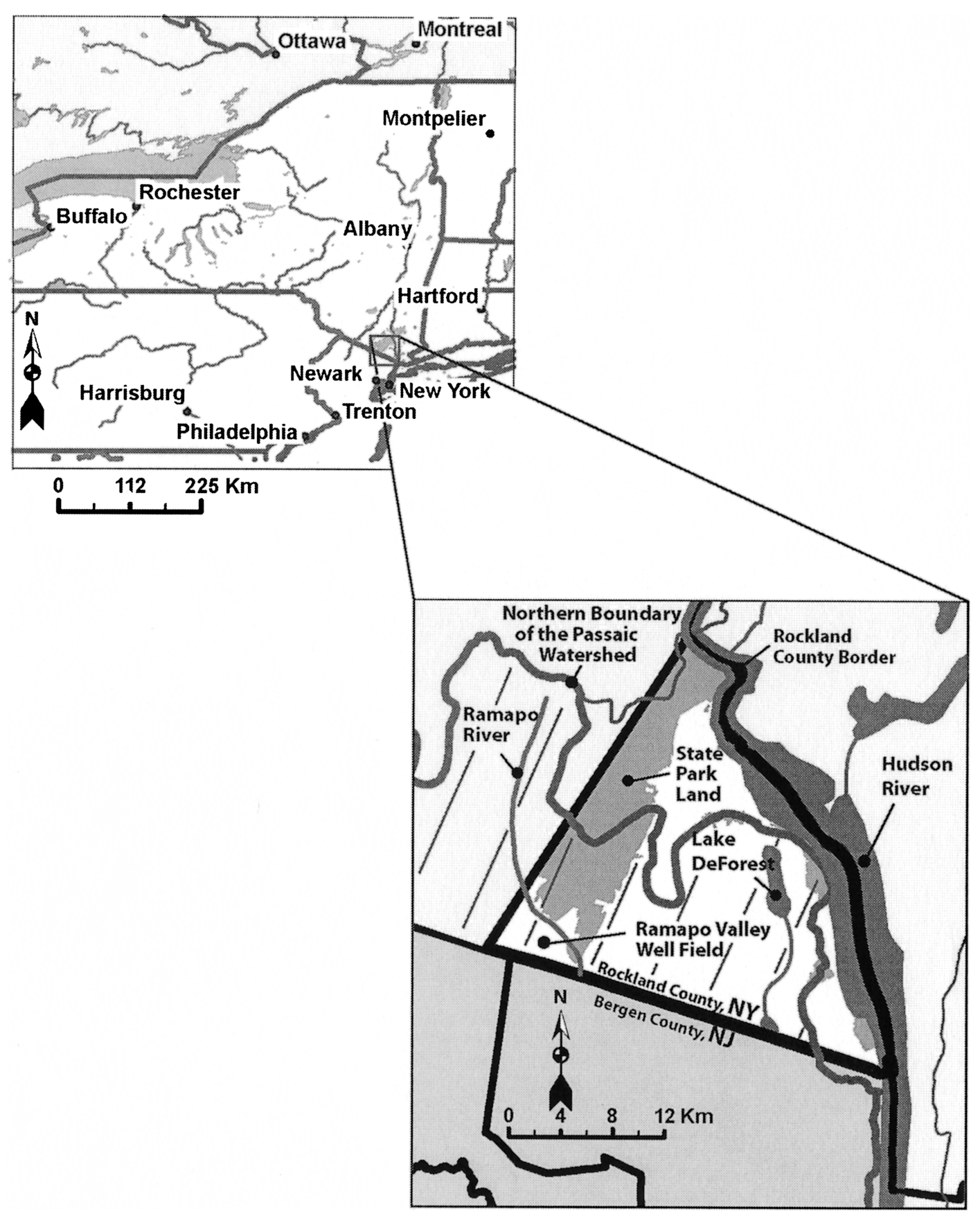

Figure 1. Reference Map of Rockland County, New York.

States. An increasing awareness, however, of the full, multidimensional aspects of securing sustainable water supplies is emerging (Downing and Bakker, 2000), and water demand and its management are important elements in the growing number of drought action plans in the United States (Wilhite, 2000). Demand side management is being considered as a tool in crafting water policy, and the concept of water scarcity has itself fallen under scrutiny and viewed outside the confines of regional climate variations (Brookshire et al., 2002). Thus, while the recent water emergencies in Rockland County provide a poignant example of emerging water shortages in a "water abundant" region, the attendant issues are of great interest much more generally. 


\section{PHYSIOGRAPHY, LAND USE, AND CLIMATE}

Rockland is the southernmost county west of the Hudson River in New York State, centered about 40 $\mathrm{km}$ northwest of New York City. It covers an area of $451 \mathrm{~km}^{2}$, with variable topography consisting of rolling hills in the eastern Piedmont region and of rather steeper terrain in western Highland areas. The more than $60 \mathrm{~km}$ eastern boundary of the county coincides with the estuary of the Hudson River. Deposits of stratified glacial fluvial sand and gravel provide numerous local aquifers, with the RamapoMahwah aquifer in western sections of the county being the most significant for public water supply. The Ramapo aquifer is hydraulically linked to flow in the Ramapo River, and recharge occurs largely within the northern 70 percent of the Ramapo River watershed, approximately $290 \mathrm{~km}^{2}$ in area (Rockland County Planning Board, 2001). The largest freshwater body in the county is Lake DeForest and on a regional scale, the Ramapo River and much of Rockland are located within the northernmost section of the Passaic watershed, which extends southward into northern New Jersey (see Figure 1).

Rockland County is comprised of five towns and 19 incorporated villages. Parks constitute the single largest land use in Rockland, at 31 percent of the total area, with over 12,000 ha being state parkland. The largest category of developed land is for singlefamily residences, accounting for 26 percent of land area, with residential areas representing 30 percent overall. The footprints of commercial and business enterprises account for 1.7 percent, and agriculture 0.3 percent. Approximately 10 percent of the county is vacant land, providing significant opportunities for continued growth, but only if appropriate infrastructure and resources such as water can be developed (Rockland County Planning Board, 2001).

The climate of the region is characterized by strong seasonality and is affected by both continental and maritime influences. The annual temperature range averages near $30^{\circ} \mathrm{C}$, with wintertime temperatures frequently below freezing and summertime temperatures often above $30^{\circ} \mathrm{C}$. Precipitation is distributed fairly evenly throughout the year, with annual totals typically in excess of $1,040 \mathrm{~mm}$. Wintertime precipitation largely occurs as storm systems travel into the region from the west and south, with the western Atlantic Ocean serving as a primary source of moisture. Snowfall is common between the months of December and March, and snowmelt is an important contributor to streamflow during spring. Moisture from both the Atlantic and the Gulf of Mexico contributes to summer rainfall, primarily produced by the passage of weak frontal systems extending southward into the region from Canada. Heavy downpours are not uncommon during summer thunderstorms, and tropical weather systems from the Caribbean and tropical Atlantic occasionally can produce large amounts of rainfall in the area, especially from late summer into November.

\section{ROCKLAND'S WATER SYSTEM}

Rockland's water supply is independent from the system that serves the New York City metropolitan area, and all of Rockland's water is derived from surface and ground water sources located within the county's borders. A private company, United Water of New York (UWNY), supplies water to about 90 percent of the population. Numerous small water companies (serving from fewer than 50 to as many as 15,000 people) provide about 7 percent of the supply, and an estimated 6,000 to 8,000 private wells account for the remaining 3 percent (see Figure 2). United Water of New York obtains its water from three main sources: Lake DeForest, a 25 million $\mathrm{m}^{3}$ reservoir that on average supplies approximately 35 percent of annual water; the Ramapo Valley Well Field (RVWF), which consists of 10 relatively shallow wells in the unconfined sand and gravel surficial aquifers of the Ramapo and Mahwah River valleys and accounts for 20 percent of production; and more than 40 wells drilled into bedrock in the Triassic Passaic Formation in the central and eastern portions of the county that produce the remaining 45 percent. The dam creating Lake DeForest was built in 1957, and a water treatment plant was installed in 1964 in order for Rockland to use the reservoir as a public water supply. Subsequent upgrades to the treatment plant have significantly increased withdrawal capacity, while the overall storage capacity of the lake has not changed since its creation. In 2004, UWNY's total water production was over 48 million $\mathrm{m}^{3}$ with a loss of roughly 17 percent due to leaks, main breaks, firefighting and other causes (UWNY, 2005). The public water supply is regulated under Part 5 of the New York State sanitary code by the state's Department of Environmental Conservation and Public Service Commission. The Rockland County Department of Health is primarily responsible for assuring water quality. Thus, the county, state, and a private company are the primary overseers of Rockland's water supply.

Rockland's reliance on ground water, roughly twothirds of total supply, is more than four times greater than the state average (excluding the New York City metropolitan area) (USGS, 1995). In addition, water withdrawal from the RVWF is directly connected to 
the flow of the Ramapo River. Ground water travels quickly through the underlying aquifer, and low flows in the Ramapo can quickly reduce recharge. Given the small size of the Ramapo watershed, the RVWF is particularly vulnerable to rather small scale, regional precipitation deficits. Permits between UWNY and the State of New York require that the RVWF be shut down when the flow of the Ramapo drops below 0.42 $\mathrm{m}^{3} / \mathrm{s}$ (8 million gallons per day), a common occurrence, especially during late summer. Yet another constraint on the water system is Lake DeForest. United Water of New York is required to release more than $0.5 \mathrm{~m}^{3} / \mathrm{s}$ of water downstream from the lake, and the annual average withdrawal rate for Rockland's water supply cannot exceed $0.53 \mathrm{~m}^{3} / \mathrm{s}$ (10 million gallons per day). With the effective storage capacity of Lake DeForest less than 40 percent of annual water use, prolonged periods of high withdrawal cannot be maintained as an offset, for example, to a reduced supply from the RVWF. In addition, a permit granted in the early 1980s by the State of New York Department of Environmental Conservation allows UWNY discretion to send additional water to New Jersey, if combined reservoir levels drop below 50 percent of capacity in that state (Lewis, 1999).

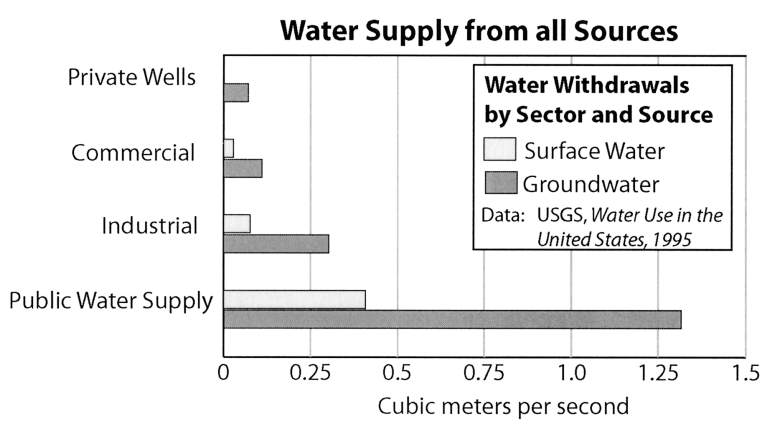

Public Water Supply (only) - Source and Deliveries
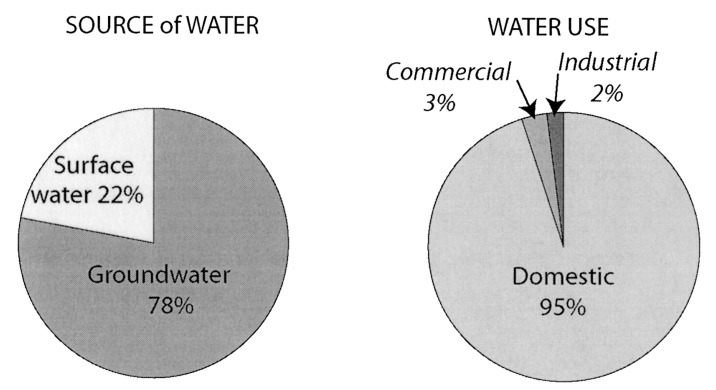

Figure 2. Water Supply Sources for Various Users in Rockland County (top) and the Overall Reliance on Surface and Ground Water Sources and Water Use by Sector (bottom). Data source: USGS (1995).
During the summer months Rockland's water supply is especially vulnerable to drought, the causes being threefold, as summarized in Figure 3. First, evaporative water losses (based on the methodology of Perkey et al., 1983, and meteorological data for Central Park) are greatest in summer, which reduces recharge, since greater evaporation results in less infiltration. Second, river flows are typically at their minimum levels. Finally, greater water withdrawals from Lake DeForest (and the system in general) typically occur at that time (Dr. Daniel Miller, Rockland County Department of Health, January 2003, unpublished data). During nonwinter months, droughts reduce reservoir and river levels nearly simultaneously, placing the burden of supply on the bedrock wells. However, prolonged dry spells have been observed to reduce ground water levels to the point that both private and public wells have occasionally not been able to supply water, further stressing the system (Lerner, 2002). Indeed, the bedrock aquifer is considered fully developed in terms of well spacing, and the Rockland County Health Department has indicated that during 2000 and 2001, withdrawals may have approached or exceeded estimated recharge rates (Rockland County Legislature, 2004). With the sustainability of the bedrock wells as a water supply source in question, the county legislature has recently approved funding for a thorough hydrological study of the aquifer. The last such study was conducted in 1959.

On shorter time scales, the ability to meet peak daily demand during the summer is universally recognized as water managers' top priority, even in the absence of drought. Average water demand for UWNY is currently around $1.5 \mathrm{~m}^{3} / \mathrm{s}$, but peak daily demand exceeds $2.3 \mathrm{~m}^{3} / \mathrm{s}$, an increase of more than 50 percent. Current development plans in the county will only push that number higher, and the recent drought emergencies declared by the Rockland County Department of Health clearly indicate that the system already is having difficulty meeting demand. In addition, a recent study of water use in New York City indicates a near linear increase in daily water consumption when the mean daily temperature exceeds roughly $25^{\circ} \mathrm{C}$ (Protopapas et al., 2000). Daily demand in New York City was roughly 5 percent above average when the mean temperature exceeded $30^{\circ} \mathrm{C}$, not an uncommon occurrence in summer. Although the relationship to Rockland's water usage is not clear, it is significant to note that, in addition to other uses, homeowners typically water their lawns during hot, dry summer days, especially during periods of drought. With over one-quarter of the land area in the county occupied by single-family residences, this use represents a significant increase in demand. To lessen the likelihood of future water emergencies, UWNY has unveiled a number of plans to increase supply, a 
point that will be returned to later. Currently, however, limited reservoir capacity coupled with a dependence on local ground water (almost one-third of which is linked to river flow in a small watershed) make the water system highly vulnerable to drought, as summarized schematically in Figure 4.
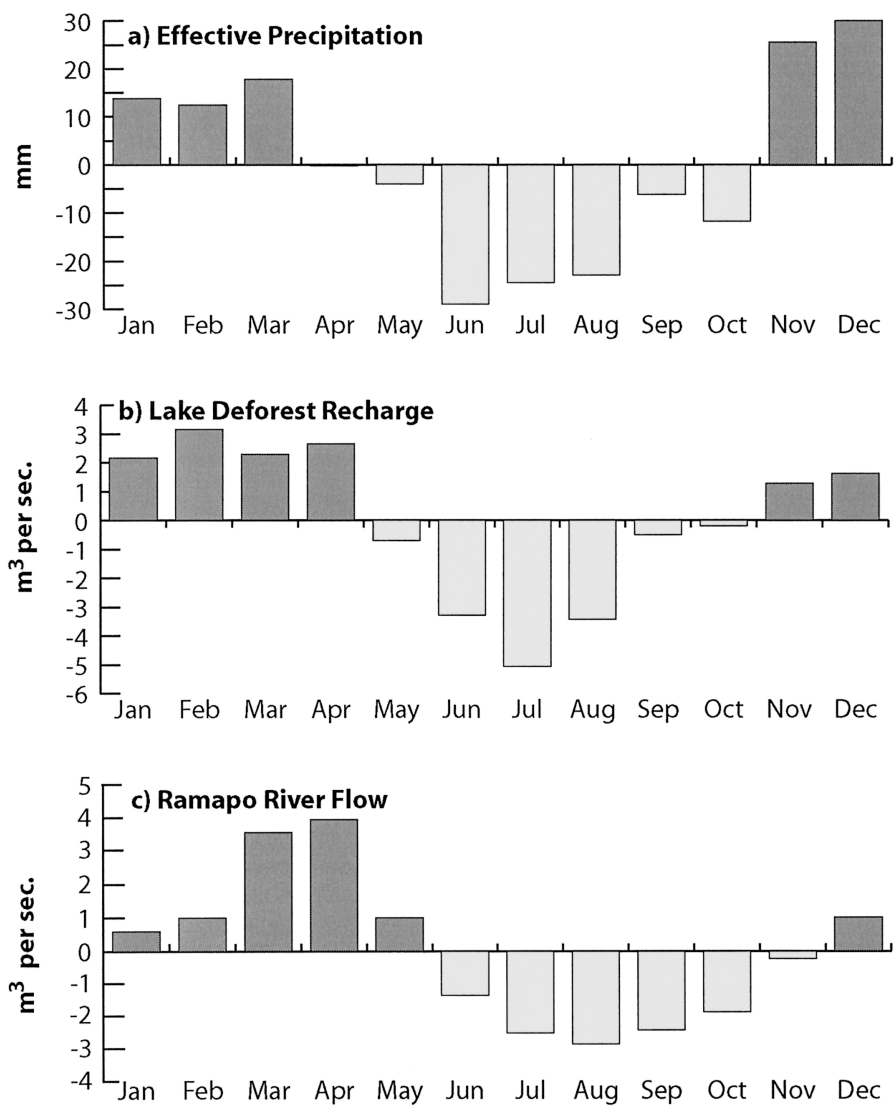

Figure 3. Monthly Differences From the Annual Average of (a) Effective Precipitation (precipitation minus evaporation); (b) Lake Deforest Recharge; and (c) Streamflow in the Ramapo River. Ramapo River data from USGS (2003).

\section{DROUGHT EMERGENCIES, DROUGHT EXTREMES?}

\section{Background}

Drought is a natural part of the climate system, and although some studies have indicated that they tend to persist longer in the interior of the country, droughts are certainly not uncommon in the northeastern United States (Karl, 1983). Were the recent drought emergencies in Rockland County the result of historic droughts, unprecedented in the climate record? If so, one would expect many water systems to be greatly stressed; if not, managers and planners cannot pin their water woes solely on what are inevitable variations in climate. What happened to trigger the recent emergencies? Figure 5 shows the monthly precipitation departures from average at Lake DeForest for 1995 to 2002, with horizontal bars indicating the time span of the Stage III drought emergencies. The 2002 stage III emergency was clearly preceded by a protracted dry period, although during the emergency, precipitation in Rockland was actually more than 30 percent above average as surface and ground water supplies were replenished. The droughts of 1999 and 1995 were much shorter. The two-month Stage III emergency of 1999 was associated with a 37 percent precipitation deficit for the period July 1998 to July 1999; during the last two months of the period, the county received less than 20 percent of average rainfall. The emergency of September 1995 was triggered by six months of deficient rainfall of 44 percent below average between March and August. While June 1995 was the driest on record in some locations, it should be noted that that the calendar year 1994 was exceedingly wet on the regional scale.

\section{Methodology}

One criterion used by Rockland County in declaring drought emergencies is based on precipitation recorded at Lake DeForest (see the Appendix), for which the monthly averages and departures from the long term (1959 to 1979) mean are routinely monitored. Data for the period 1995 to 2002 were obtained from the Health Department (Dr. Daniel Miller, Rockland County Department of Health, January 2003, unpublished data), and in order to place the recent droughts into historical context, precipitation records for several observing stations throughout the region were also utilized. Presented here are analyses for the period 1900 to 2002 based on monthly precipitation averaged over six stations located in the greater Rockland County region (see Table 1) all generally within the same climate zone (Fovell and Fovell, 1993; DeGaetano, 1996). To be consistent with records maintained by the Rockland Health Department, a 1959 to 1979 base period is used to define monthly precipitation normals. Using a more standard 1971 to 2000 base period does not significantly affect the results.

Since no universal definition of drought exists (drought is a location specific and use specific phenomenon), an assessment of relative drought severity based on a single index may be misleading (Heim, 2002). Therefore, a variety of measures was used to examine past droughts in the region. First, a simple 12-month running average of monthly departures 


\section{a) Wet Conditions}

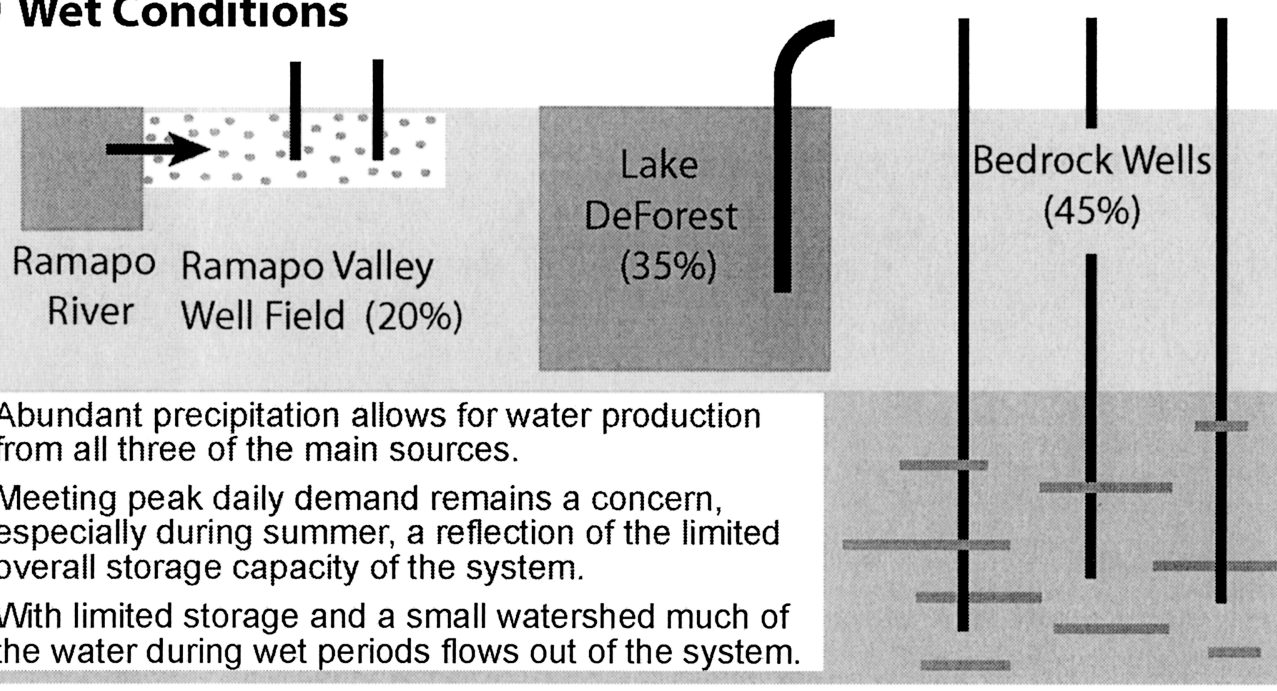

\section{b) Drought}

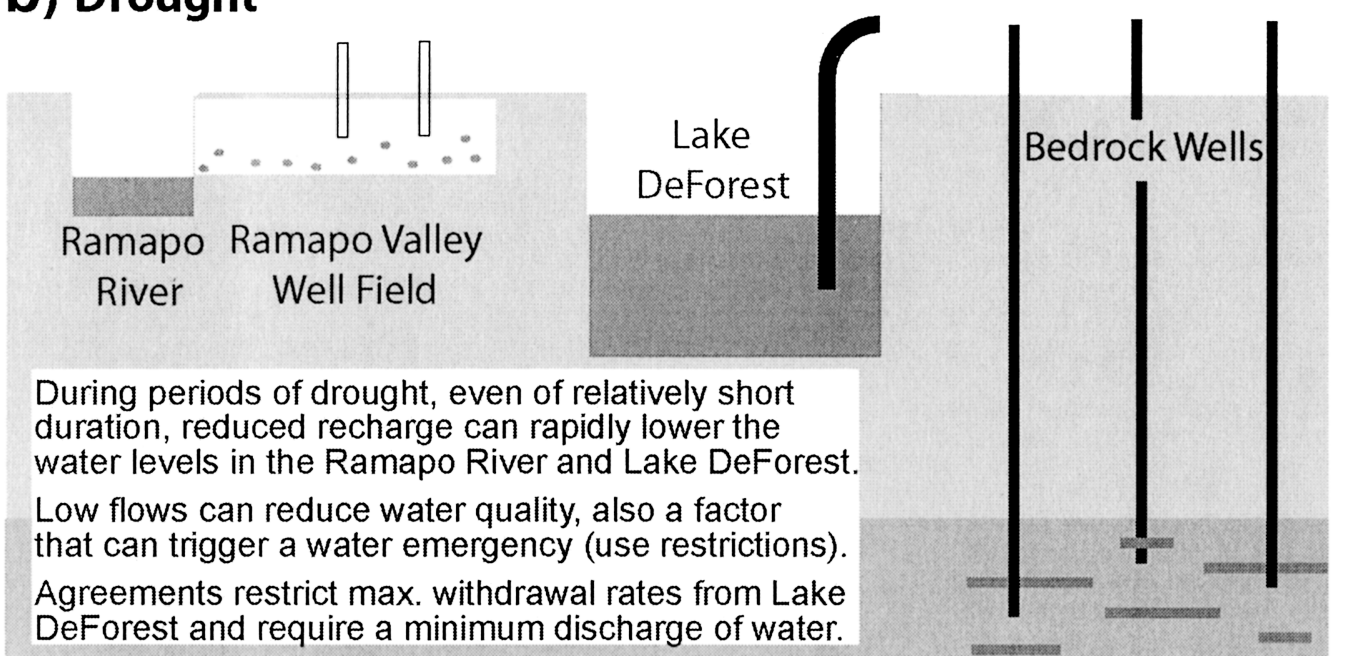

Figure 4. Schematic Overview of (a) the Main Features of Rockland County's Water System During Generally "Wet" Conditions, Including Percentage of Average Annual Production (in parentheses); and (b) Some Important Constraints on the System During Drought.

from normal precipitation is considered for the sixstation average. Using this measure, drought onset is defined as the first month that the running average becomes negative; it terminates when the index becomes positive. The magnitude of a drought is defined as the sum of monthly precipitation departures between onset and termination, and only those drought events lasting six months or more were included in the analysis (since the droughts during the recent water emergencies were observed to persist for at least six months). This index, though simple, has the advantage of being easily interpreted, and for the northeastern United States, its variations are closely related to those of the Palmer Drought Severity Index (PDSI) that studies have shown is highly correlated with reservoir levels in southeastern New York State, especially when water consumption data are available (DeGaetano, 1999).

However, with only a few years of reservoir level data available for Lake DeForest, long term associations between drought conditions (based on any index) and water level could not be established in a robust manner. Given the small size of the watershed from which Rockland derives its water supply, it is 


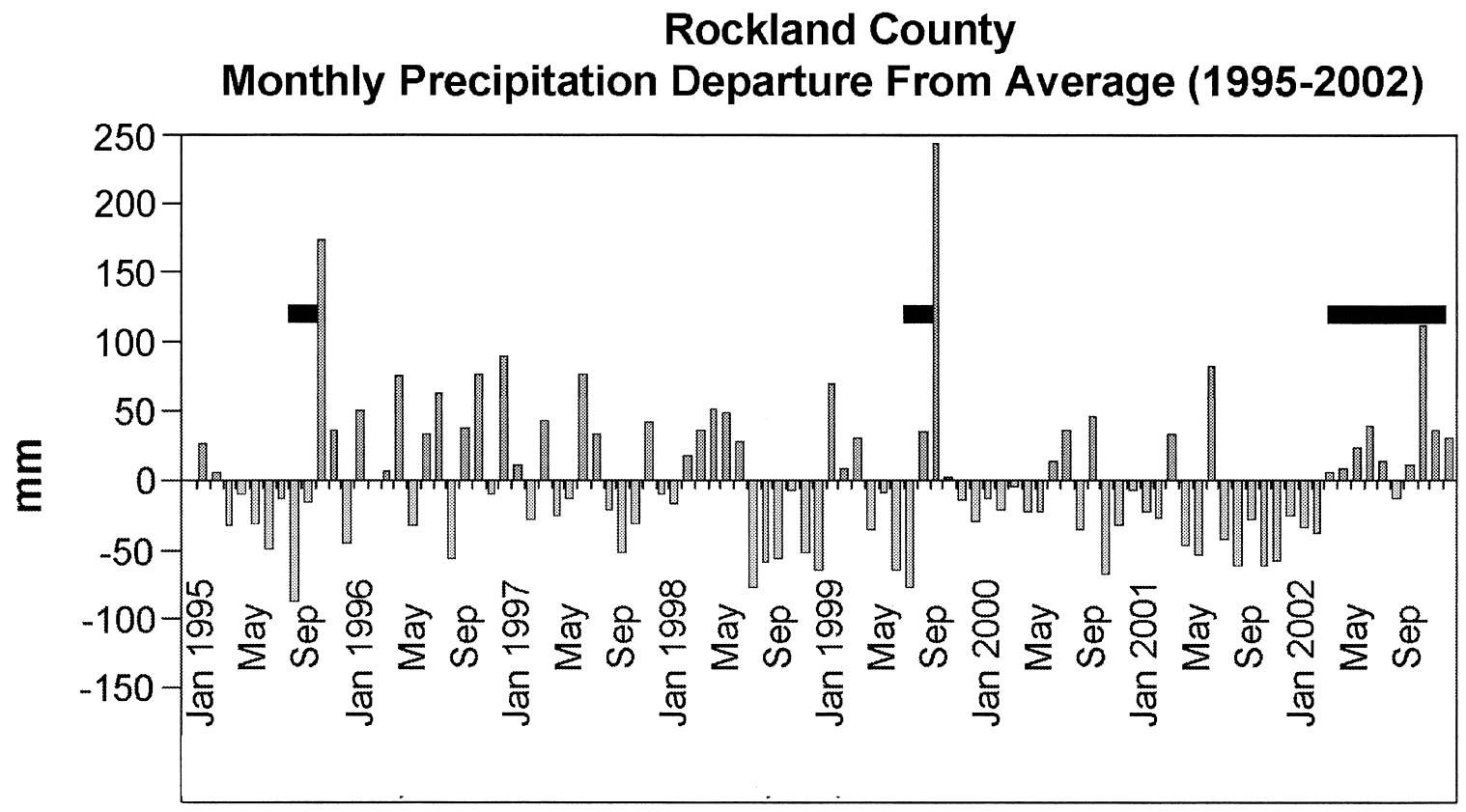

Figure 5. Monthly Precipitation Departures From Average Measured at Lake DeForest (1950 to 1979 climate normals). Black horizontal bars indicate the duration of the three recent Stage III drought emergencies (associated dates shown at the bottom of the figure). Data Source: Dr. Daniel Miller, Rockland County Department of Health, January 2003, unpublished data.

TABLE 1. Locations of Precipitation Stations Used in the Drought Analysis.

\begin{tabular}{|c|c|c|c|}
\hline Name & Latitude & Longitude & $\begin{array}{c}\text { Elevation } \\
\text { (m) }\end{array}$ \\
\hline Charlotteburg Reservoir & $41.04^{\circ} \mathrm{N}$ & $74.44^{\circ} \mathrm{W}$ & 232 \\
\hline Port Jervis & $41.39^{\circ} \mathrm{N}$ & $74.69^{\circ} \mathrm{W}$ & 143 \\
\hline Central Park & $40.79^{\circ} \mathrm{N}$ & $73.97^{\circ} \mathrm{W}$ & 40 \\
\hline Yorktown Heights & $41.27^{\circ} \mathrm{N}$ & $73.8^{\circ} \mathrm{W}$ & 204 \\
\hline West Point & $41.39^{\circ} \mathrm{N}$ & $73.97^{\circ} \mathrm{W}$ & 98 \\
\hline Mohonk Lake & $41.77^{\circ} \mathrm{N}$ & $74.16^{\circ} \mathrm{W}$ & 380 \\
\hline
\end{tabular}

conceivable that shorter term droughts (i.e., those not necessarily well captured by a 12 -month running average) may also lead to disruptions in water supply. Therefore, two additional drought measures were employed that are able to capture droughts of shorter duration. The first is the PDSI averaged over the Hudson Valley climate division (which roughly extends from Albany, New York, southward to Rockland County), and the second is the Standardized Precipitation Index (SPI) (McKee et al., 1995). The SPI is in wide use and has been used for a number of applications. The SPI is based solely on precipitation and provides a relative measure of accumulated precipitation over a given period of interest, ranging from a month to two years or more. Here, the six-station average precipitation was used to compute the SPI for overlapping six-month periods from 1900 to 2002 . Negative values of the PDSI and SPI indices indicate drier than normal conditions (positive, wetter), and from a meteorological perspective, a PDSI (SPI) value of -2.0 (-1.0) is generally considered a threshold value for "moderate" drought conditions. For comparison with the droughts that occurred during the recent water emergencies, historical drought events were required to have PDSI values below -2.0 for at least one month and six-month SPI values of less than -1.0 for at least two consecutive months to be considered. In a manner similar to that used for the 12-month running average, the onset of a drought is indicated when the PDSI and SPI indices first become negative, and it terminates when these indices return to positive values. Accumulated precipitation deficits were 
also computed over the duration of individual drought events identified using the PDSI and SPI. As a final comparison, estimates of the PDSI based on tree-ring data for the region (Cook and Krusic, 2004) have been used in order to extend the historical data back 500 years.

\section{Results}

Figure 6 displays the magnitude and duration of all droughts in the greater Rockland County region that lasted six months or more based on the 12-month running average and the PDSI. The gray, filled circles on the plots indicate the three droughts associated with recent water emergencies. It is clearly seen that even during 2001 to 2002, the most severe of the recent droughts, the magnitude and duration of the event were well within the bounds of past variability. Indeed, the drought of the 1960s, the most severe of the previous century, lasted roughly four times longer than the 2001 to 2002 drought, with an associated precipitation deficit more than four times larger (even more for events based on the PDSI). The 1995 and 1999 droughts were well below the median values of both magnitude and duration based on the 12-month running average (the 10th percentile or less). Based on the PDSI, the 1995 and 2001-2002 events had magnitudes and durations slightly above median values, with the 1999 event well below the median for both measures. In addition, an inspection of the full 103-year record also reveals (not shown) that following the 1960s drought, there was a period of more than 13 consecutive years when the PDSI dropped below -2.0 (i.e., "moderate" drought level) during only four nonconsecutive months. As will be shown in the next section, the population of Rockland has roughly doubled since the severe drought of the 1960s. Also noteworthy in Figure 6 is the observation that the severity of the 1981 drought was comparable to the 2002 event, yet it did not result in water emergencies of the type experienced most recently in Rockland.

Drought events identified using the 6-month SPI are summarized in Figure7a. In this plot the relative rank of both magnitude and duration of the three recent droughts are seen to increase somewhat compared to those seen in Figure 6. On this time scale the 2001 to 2002 drought again stands out as the strongest of recent events, though still remaining far less severe than the drought of the 1960s. The characteristics of the 1995 and 1999 drought episodes, however, do not depart significantly from the median values (particularly in terms of magnitude), and it is again noteworthy that the 1981 drought event was of similar severity. Finally, the 1960s drought can itself be viewed in historical perspective by considering annual tree-ring data that have been calibrated to the PDSI. As seen in Figure 7b, droughts of qualitatively comparable severity or duration (and prior) to the 1960s event have occurred roughly eight times since 1500 and are spaced fairly uniformly in time. Thus, while the precipitation deficits associated with the drought of the 1960s appear as an outlier in these analyses, the return of such drought conditions within the next few decades would certainly not be unprecedented.
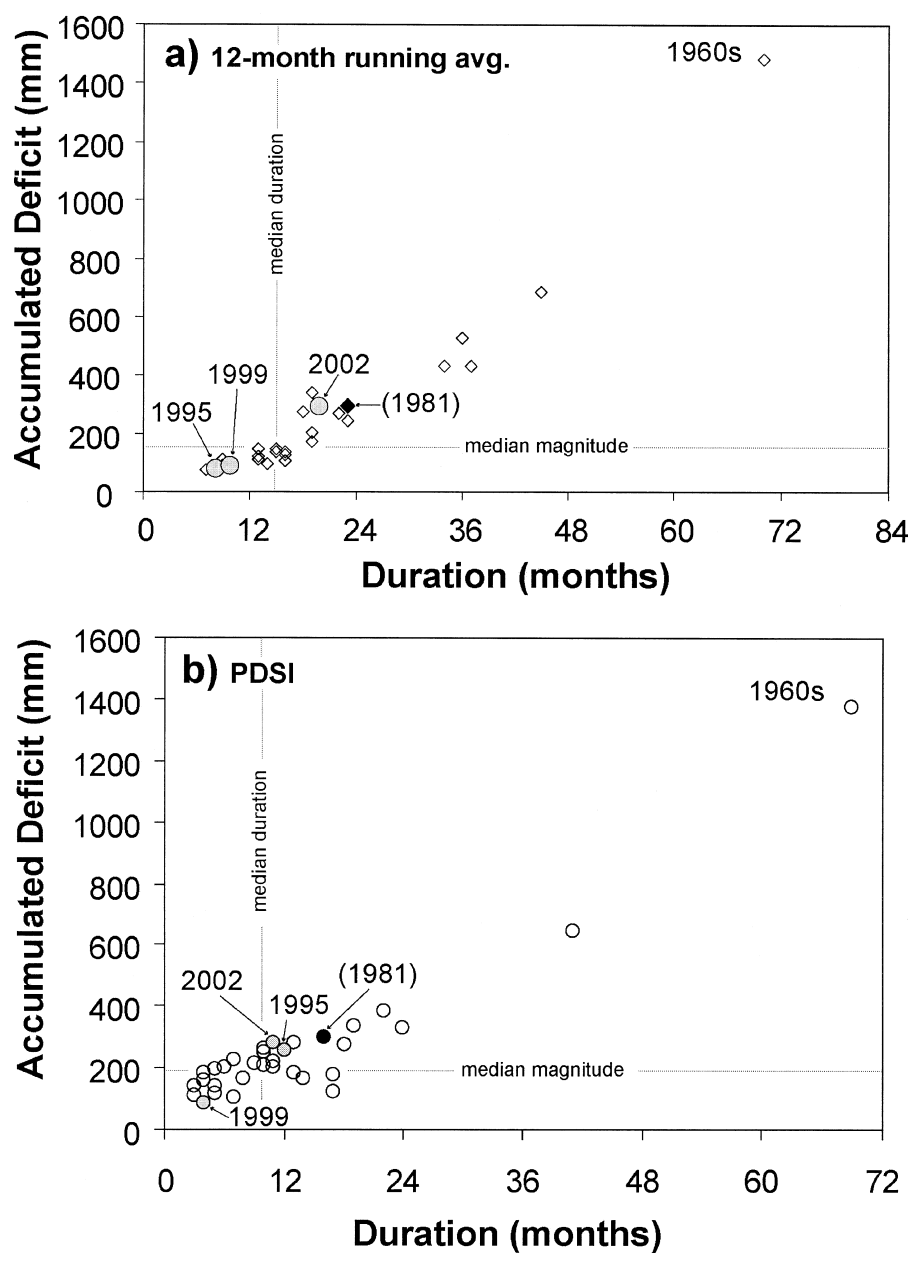

Figure 6. Accumulated Deficit of Precipitation Versus Duration for (a) 28 Drought Events Identified Using a 12-Month Running Average of Monthly Precipitation Departures From Average; and (b) 33 Drought Events Identified by the PDSI for the Hudson Valley Climate Division.

The gray, filled circles indicate the three recent droughts; the 1981 drought is indicated by solid black symbols. The period of analysis is 1900 to 2002 .

Based on these results, one is left to conclude that although some individual months during the recent three droughts were exceptionally dry, the accumulated precipitation deficits and overall duration of these 
drought events not only fell well within the bounds of past climate variability, but by several measures were far from exceptional. In addition, there has been a relative lack of drought since the $1960 \mathrm{~s}$, a period of rapid development, population growth, and increased water demand in Rockland. A formal mechanism for declaring drought emergencies in the county was not promulgated until 1983 (inspired by the drought of 1981) and was only put into effect starting with the drought of 1995 . With water supply capacity essentially static over the past three decades, there is considerable evidence to support the conclusion that the recent drought emergencies in Rockland County were not the result of drought alone but were associated with a burgeoning demand for water.
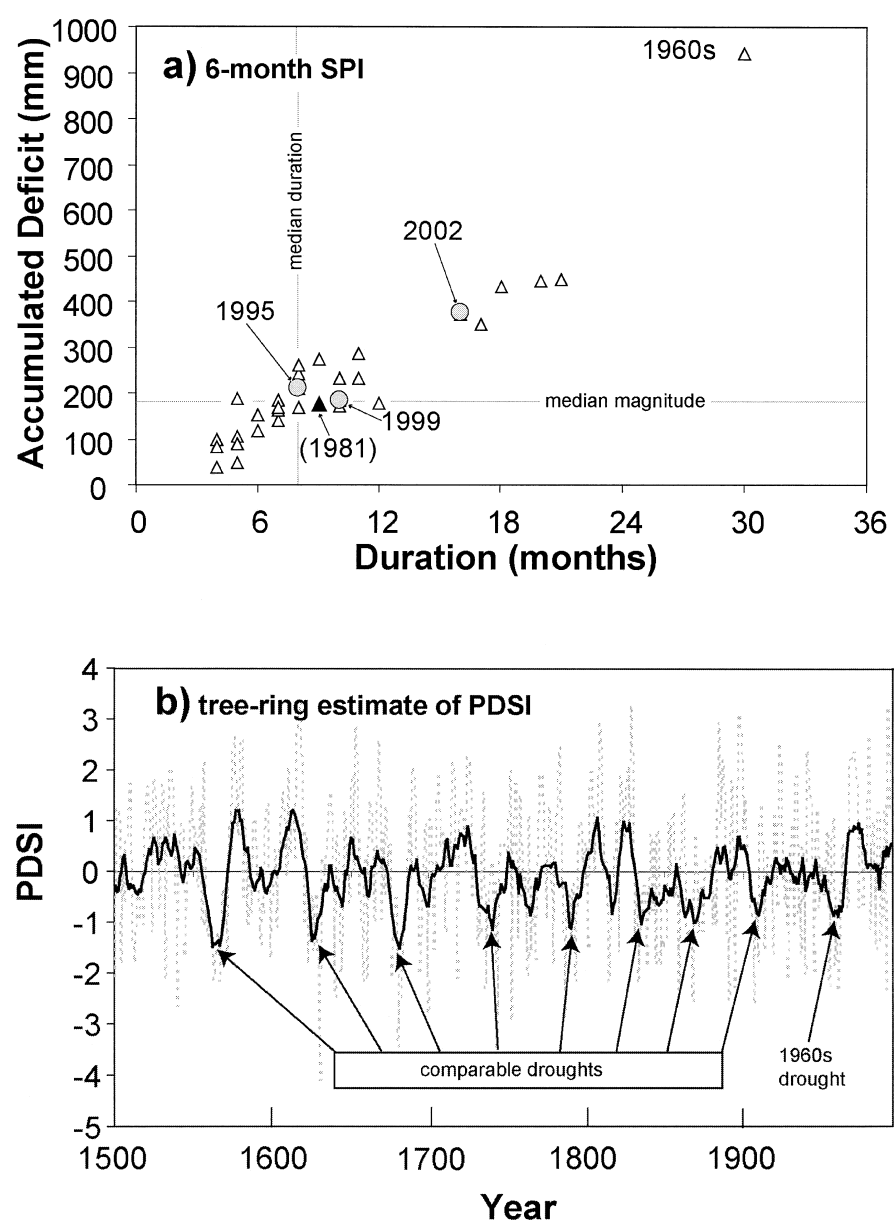

Figure 7. (a) Accumulated Deficit of Precipitation Versus Duration for 32 Drought Events Identified Using the Six-Month SPI; (b) Time Series of Estimated July PDSI for the Past 500 Years (ending in 2003) Based on Gridded Tree-Ring Data for Southeastern New York (using the point $75.0^{\circ} \mathrm{W}, 42.5^{\circ} \mathrm{N}$ ). The dashed line in (b) indicates July estimates; the solid black line is a five-year running average.

\section{ROCKLAND'S DEMOGRAPHICS}

As seen in Figure 2, most of Rockland County's water demand is used to supply private residences. In 2003, more than 72 percent of Rockland's population lived in owner occupied housing, more than twothirds of which consist of single-family units (New York State AFL-CIO, 2003). Rockland has the eighth highest population density of the 62 counties in New York State, which at 635 people per $\mathrm{km}^{2}$ is more than four times the state average, although nowhere near the density of New York City's five boroughs (10,235 per $\mathrm{km}^{2}$ ) (U.S. Census Bureau, 2003). The population of Rockland has more than tripled since 1950, with an average growth rate for the period 1930 to 2000 of more than 27 percent per decade, peaking at greater than 68 percent per decade in the 1970s (New York State Data Center, 2000). During the 1990s, growth slowed to around 8 percent per decade overall, although the Town of Ramapo in the western part of the county, where most housing already exists, continued to grow at twice that rate (New York State Data Center, 2003). During the past half-century, water supply infrastructure and home building have developed unevenly, with housing pulling ahead of water. This decoupling has occurred in a political environment in which the county, state, and a private water company oversee (most of) the water supply, while development is largely under the control of local towns and villages. Indeed, recent incorporation of villages within the county has been used as a primary mechanism to either enhance or inhibit development (Rockland County Planning Board, 2001). The overall situation has allowed for a "blame the other side" posture when water shortages emerge. While occasional droughts have brought such mismatches to light over the past 20 years (e.g., see Weisman, 1985), a generally wetter than average climate has allowed them to be largely ignored (see Figure 8).

\section{AFFORDABLE HOUSING, AFFORDABLE WATER}

Coupled with an overall increase in residential development is a growing need for affordable housing in Rockland. The median cost of home ownership is the third highest among all counties in the state, with more than one-third of homeowners and 40 percent of renters paying more than 30 percent of their income for housing (U.S. Census Bureau, 2003). Over the past decade, the increase in the median cost of owning or renting a home has outpaced the increase in median income for both groups of residents in the county 


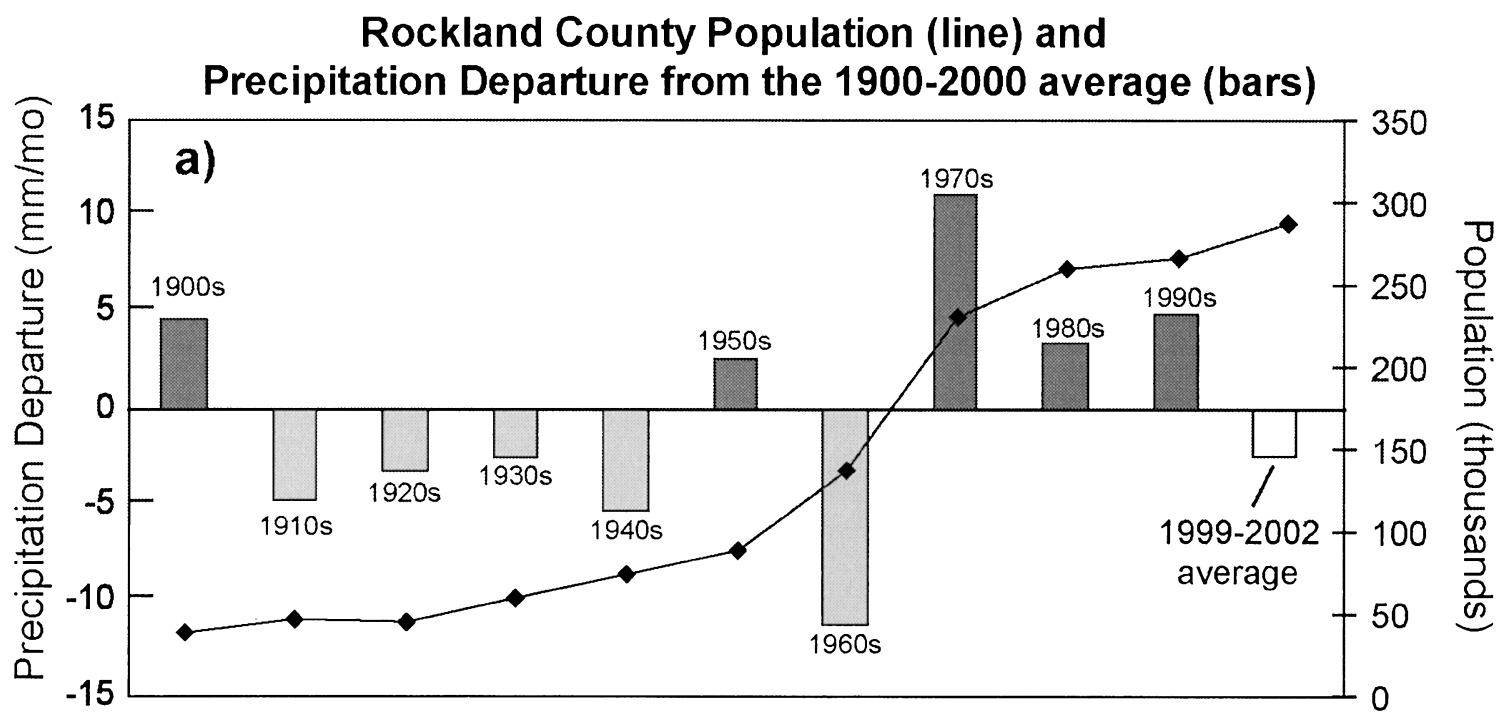

Rockland County Total Water Withdrawls

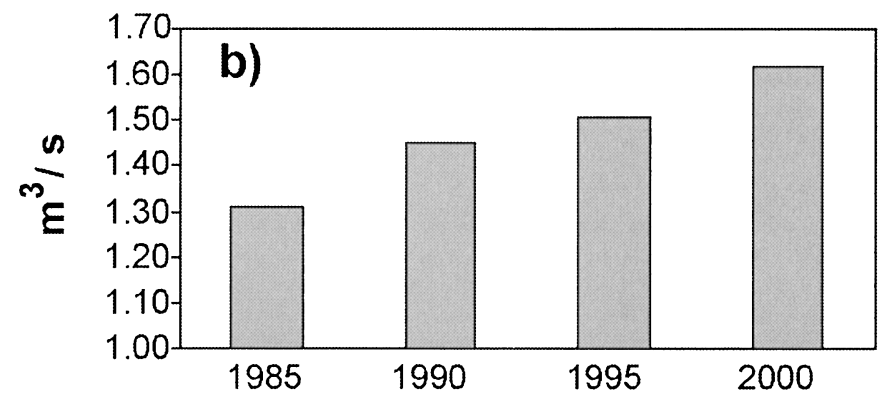

Figure 8. (a) Population, by Decade, of Rockland County is Shown by the Solid Line (plotted at the midpoint of each decade). The departure of 10-year average precipitation from the 1900 to 2000 mean is indicated by vertical bars. The departure in average precipitation for January 1999 to December 2002 from the 1900 to 2000 mean is indicated by the unfilled bar on the right side of the plot. (b) Total Water Withdrawals in Rockland County Over the 15-Year Period 1985 to 2000 , Based on Estimates Obtained From the USGS (2005) for 1985, 1990, 1995, and 2000. Population data from New York State Data Center (2000, 2003). Precipitation data from NCDC (2003).

(New York State AFL-CIO, 2003). Local zoning often precludes higher density or multifamily houses, placing further upward pressure on prices. A significant rezoning of properties to allow for construction of single-family and multifamily dwellings is one option recently adopted by the Town of Ramapo. However, with more units and downzoning (the latter recently used in the Village of Haverstraw to allow for approximately 800 new units), what will be the attendant increase in water demand? That is one question being asked by critics whose concerns range from adequate sewage facilities to water quality and the preservation of open space. Projections in the Ramapo draft plan indicated an increase in average daily demand of up to 3 percent by 2010, and UWNY projects an increase in peak demand (for the entire county) of 6 to 10 percent, increasing to as high as 20 percent by 2020 (Town of Ramapo, 2002). United Water of New York insists that it will be able to meet the increased demand, but to do so will necessitate serious upgrades to the current water infrastructure, with UWNY customers ultimately footing the bill.

Approaches to meeting future water demands are quite fragmented. Plans by UWNY to increase supply focus mainly on augmenting flow in the Ramapo River to allow the RVWF to remain in operation, especially during summer. However, these plans rely on surface water bodies significantly smaller than Lake DeForest (and still located within the county) or on discharge from water treatment facilities. Some state lawmakers have suggested that the county create a water authority to enable it to enhance its 
surface water storage capability and to sell water back to UWNY. This would eliminate reliance on UWNY to develop such infrastructure, but the plan has not garnered much attention since enhanced supply is primarily needed in summer, thereby limiting the authority's ability to recoup costs. Desalinization of Hudson River water is another option, but such production is much more expensive than withdrawing ground water. Water conservation has been helpful in keeping winter demand fairly steady, but not so in summer. Examples from successful demand management programs go beyond voluntary conservation to include adoption of alternative price structures, reducing leaks and wasted water, and developing infrastructure to enhance supply from gray water or treatment plants (Dziegielewski and Baumann, 1992). Simply increasing the price of water to reduce demand seems plausible, but higher residential rates are a tough sell politically, especially in light of current volume discounts for industrial users. The UWNY cannot unilaterally raise rates, which are set by the New York Public Service Commission and based on the cost of providing water service. In relying so heavily on local water resources, the county will find it difficult to meet future demand, at least through historical means. But as seen in the case of New York City's water supply, forging regional agreements between disparate stakeholders is possible with concerted effort (Platt et al., 2000). If little is done to address the problem, drought emergencies are sure to emerge more frequently. Indeed, Figure 9 indicates the number of drought emergencies that could have been declared over the past 127 years based on Rockland's recently adopted precipitation criteria and data for Central Park. Conditions for Stage III emergencies, the type considered here, were met more than 50 times, and 16 Stage IV emergencies (never declared in Rockland to date) occurred over the same period.

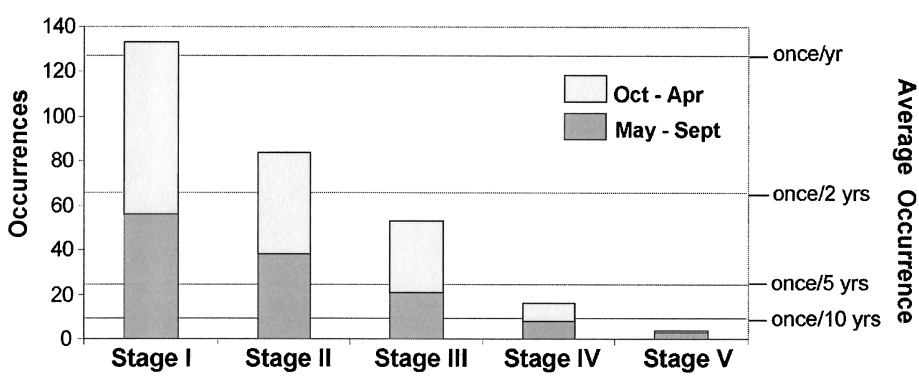

Figure 9. Number of Occurrences (left axis) When Precipitation Criteria Necessary for Declaring Drought Emergencies in Rockland County Were Met Based on Data for Central Park 1875 to 2001. Dark (light) bars indicate criteria met during May to September (October to April). The average rate of occurrence is shown on the right axis.

\section{CONCLUSIONS}

Rockland County has a climate and geographical location both suggestive of an abundant water supply. Yet three drought emergencies in eight years have raised concern about the reliability of its water system. An analysis of the severity of the recent droughts indicates they were not only well within the bounds of past climate variability, but by several measures, were far from exceptional. Coupled with the fact that the capacity of the water supply system has remained essentially static over the past few decades, one is left to conclude that rapid and continuing development, particularly of private residences, cannot be ignored as a significant contributing factor to the recent water emergencies. Current plans to enhance supply all focus on water from within Rockland County, and approaches are highly fragmented since development is largely controlled by local communities, while water supply is overseen by the county, state, and a private water company. A realistic solution to the problem will require the cooperation of local, county, state, and federal authorities, and an equitable means of paying for the improvements remains a challenge.

Rockland's political environment, coupled with a historical reliance on local water supplies, has left it particularly vulnerable to shortages. However, high development rates in many counties of the United States are also placing an increasing strain on water supplies. Indeed, a recent study by the U.S. General Accounting Office (USGAO) reported that 36 states (out of the 47 that participated) expect water shortages in the next 10 years - under normal climate conditions. That number jumps to 46 of 47 if a drought should develop (USGAO, 2003). The linkages between development, water use, and sustainability are universal and need to be recognized if stable water supplies are to be maintained. With variations in climate inevitable, taking a "business as usual" approach will result in drought emergencies of increasing frequency and severity in the years ahead, even in the "water abundant" northeastern United States.

\section{APPENDIX \\ DECLARING WATER EMERGENCIES IN ROCKLAND COUNTY}

The authority to declare a drought emergency is held by the Rockland County Commissioner of Health as promulgated under Article V of the County Sanitation Code, revised in 2002 (Rockland County Department of Health, 2002). Five stages of drought emergency have been defined based on: precipitation 
departures from average for the Rockland County Health District (relative to a 1959 to 1979 base period); the ability to augment base flow of the Ramapo River; water levels in Lake DeForest; and general concerns for public health and safety. Rule curves have been codified for minimum water capacity for augmentation of base flow in the Ramapo River for stages I to III and for water levels in Lake DeForest for all five stages. Precipitation criteria vary with the stage of the emergency and are described in Table A1. A given stage of emergency may be declared if any of the defining criteria are met.

TABLE A1. Precipitation Thresholds for Declaring Drought Emergencies in Rockland County.

\begin{tabular}{ll}
$\begin{array}{c}\text { Level of } \\
\text { Emergency }\end{array}$ & \multicolumn{1}{c}{ Precipitation Threshold } \\
\hline Stage I & Previous two months $<60$ percent of average \\
Stage II & Previous three months $<60$ percent of average \\
Stage III & Previous four months $<60$ percent of average \\
Stage IV & Previous six months $<60$ percent of average \\
Stage V & Previous 12 months $<65$ percent of average \\
\hline
\end{tabular}

Source: Rockland County Department of Health (2002).

The relatively short (two to six months) time horizons listed in Table A1 indicate the sensitivity of the water supply system to seasonal variations in climate. Historical precipitation data for Central Park have been used to examine how often the various precipitation criteria would have been met over the period 1875 to 2001. The results are displayed in Figure 9.

\section{ACKNOWLEDGMENTS}

The authors thank Dr. Daniel Miller of the Rockland County Department of Health and Mr. Scott Cuppett of the New York State Department of Environmental Conservation for their careful reading of an earlier version of this manuscript. The comments and suggestions of three anonymous reviewers also helped to clarify a number of points and improve the paper. The provision of precipitation and water supply data from the Rockland County Department of Health is very much appreciated, as is the assistance of Judi Hunderfund, Emily Grover-Kopec, and John del Corral. This paper is funded in part by a grant/cooperative agreement from the National Oceanic and Atmospheric Administration (NOAA), NA050AR4311004. The views expressed herein are those of the authors and do not necessarily reflect the views of NOAA or any of its subagencies.

\section{LITERATURE CITED}

Brookshire, D.S, H.S. Burness, J.M. Chermak, and K. Krause, 2002. Western Urban Water Demand. Nat. Resources J. 42:873-898.

Cook, E.R. and P.J. Krusic, 2004. The North American Drought Atlas. Lamont-Doherty Earth Observatory and the National Science Foundation. Available at http://iridl.ldeo.columbia.edu/ SOURCES/.LDEO/.TRL/.NADA2004/.pdsi-atlas.html. Accessed in March 2005.

DeGaetano, A.T., 1996. Delineation of Mesoscale Climate Zones in the Northeastern United States Using a Novel Approach to Cluster Analysis. J. Clim. 9(8):1765-1782.

DeGaetano, A.T., 1999. A Temporal Comparison of Drought Impacts and Responses in the New York City Metropolitan Area. Climatic Change 42:539-560.

Downing, T.E. and K. Bakker, 2000. Drought Discourse and Vulnerability. In: Drought: A Global Assessment, D.A. Wilhite (Editor). Routledge, New York, New York, Vol. II, pp. 213-230.

Dziegielewski, B. and D.D. Baumann, 1992. Tapping Alternatives: The Benefits of Managing Urban Water Demands. Environment, November, pp. 6-11, 35-41.

Fovell, R.G. and M.C. Fovell, 1993. Climate Zones of the Conterminous United States Defined Using Cluster Analysis. J. Clim. 6(11):2103-2135.

Heim, R.R., 2002. A Review of Twentieth-Century Drought Indices Used in the United States. Bull. Am. Meteorol. Soc. 83(8):11491165.

Karl, T.R., 1983. Some Spatial Characteristics of Drought Duration in the United States. J. Clim. and Applied Meteor. 22(8):13561366.

Lerner, Jane, 2002. Dry Wells a New Reality in Rockland. The Journal News, April 7, 2002.

Lewis, Raphael, 1999. Parched Rockland Draws Line in Sand. Bergen Record, July 31, 1999.

McKee, T.B., N.J. Doesken, and J. Kleist. 1995. Drought Monitoring With Multiple Time Scales. Preprints, 9th Conference on Applied Climatology, Dallas, Texas. American Meteorological Society, Boston, Massachusetts, pp. 233-236.

NCDC (National Climatic Data Center), 2003. Global Historical Climate Network. Available at http://iridl.ldeo.columbia.edu/ SOURCES/.NOAA/.NCDC/.GHCN/.v2beta/.prcp/. Accessed in January 2003.

New York State AFL-CIO, 2003. The Crisis of Affordable Housing for Hudson Valley's Working People. Available at http://www. nysaflcio.org/hv_housing_report.htm. Accessed on September 29, 2003.

New York State Data Center, 2000. Population of New York State by County 1790 to 2000. Available at http://www.nylovesbiz.com/ nysdc/StateCountyPopests/CountyPopHistory.PDF. Accessed on September 30, 2003.

New York State Data Center, 2003. Total Population Change for New York Local Government Areas, 1990 to 2000. Available at http://www.nylovesbiz.com/nysdc/census2000/corrections/pltab1. pdf. Accessed on September 30, 2003.

Perkey, D.J., K.N. Young, and C.W. Kreitzberg, 1983. The 1980-81 Drought in Eastern Pennsylvania. Bull. Am. Meteorol. Soc. 64(2):140-147.

Platt, R.H., P.K. Barten, and M.J. Pfeffer, 2000. A Full Clean Glass? Managing New York City's Watersheds. Environment, June, pp. 8-20.

Protopapas, A.L., S. Katchamart, and A. Platonova, 2000. Weather Effects on Daily Water Use in New York City. Journal of Hydrologic Engineering, July, pp. 332-338.

Raver, Anne, 2002. NATURE: Hope Springs Eternal In a Dry Season. New York Times, March 14, 2002, F1. 
Rockland County Department of Health, 2002. Rockland County Sanitary Code, Article V: Mandatory Water Conservation Measures. Available at www.co.rockland.ny.us/health/pdf/articleV. pdf. Accessed on September 30, 2003.

Rockland County Legislature, 2004. Rockland County Legislature's Resolution on U.S. Geological Survey. Available at www.co. rockland.ny.us/Legislature/USGS.htm. Accessed on December 20, 2004.

Rockland County Planning Board., 2001. Rockland County: River to Ridge - A Plan for the 21st Century. Rockland County Department of Planning. Available at http://www.co.rockland.ny.us/ planning/landuse/complan.htm. Accessed on September 26, 2003.

Town of Ramapo, 2002. Town of Ramapo Comprehensive Plan Draft Generic Environmental Impact Statement, Part IIIC: Community Resources. Available at http://www.ramapo.org/ townhall/dgeis/SectionIII.C-CommunityResou.pdf. Accessed on September 23, 2003.

U.S. Census Bureau, 2003. Profile of Selected Housing Characteristics: 2000 for Rockland County, New York. Available at http://factfinder.census.gov/bf/_lang=en_vt_name=DEC_2000_ SF3_U_DP4_geo_id=05000US36087.html. Accessed on September 22, 2003.

USGAO (U.S. General Accounting Office), 2003. Freshwater Supply: States' Views of How Federal Agencies Could Help Them Meet Challenges of Expected Shortages. U.S. General Accounting Office, GAO-03-514, Washington, D.C.

USGS (U.S. Geological Survey), 1995. Estimated Water Use in the United States in 1995: Downloading 1995 Water-Use Data. Available at http://water.usgs.gov/watuse/spread95.html. Accessed on September 22, 2003.

USGS (U.S. Geological Survey), 2005. USGS, Water Use in the United States. Available at http://water.usgs.gov/watuse/. Accessed in January 2005.

USGS (U.S. Geological Survey), 2003. Monthly Streamflow Statistics for New York. Available at http://nwis.waterdata.usgs.gov/ ny/nwis/monthly/?site_no=01387400\&agency_cd=USGS. Accessed in March 2003.

UWNY (United Water of New York), 2005. Annual Water Quality Report 2004. Available at http://www.unitedwater.com/uwny/ pdfs/dNY.pdf. Accessed in October 2005.

Vorosmarty, C.J., P. Green, J. Salisbury, and R.B. Lammers, 2000. Global Water Resources: Vulnerability From Climate Change and Population Growth. Science 289:284-288.

Weisman, R.A., 1985. The 1980-81 Drought in Southeastern New York. Bull. Am. Meteorol. Soc. 66(7):788-794.

Wilhite, D.A., 2000. State Actions to Mitigate Drought. In: Drought: A Global Assessment, D.A. Wilhite (Editor). Routledge, New York, New York, Vol. II, pp.149-157. 